\title{
APPLYING TOPSIS AND COOPERATIVE GAME THEORY IN AIRLINE MERGING AND COALITION DECISIONS
}

Oliver F. Shyr

Department of Urban Planning, National Cheng Kung University, Tainan, Taiwan., ofshyr@mail.ncku.edu.tw

Yi-Pin Kuo

Trans Asia Airways, Taipei, Taiwan.

Follow this and additional works at: https://jmstt.ntou.edu.tw/journal

Part of the Business Commons

\section{Recommended Citation}

Shyr, Oliver F. and Kuo, Yi-Pin (2008) "APPLYING TOPSIS AND COOPERATIVE GAME THEORY IN AIRLINE MERGING AND COALITION DECISIONS," Journal of Marine Science and Technology. Vol. 16: Iss. 1, Article 2.

DOI: $10.51400 / 2709-6998.1992$

Available at: https://jmstt.ntou.edu.tw/journal/vol16/iss1/2

This Research Article is brought to you for free and open access by Journal of Marine Science and Technology. It has been accepted for inclusion in Journal of Marine Science and Technology by an authorized editor of Journal of Marine Science and Technology. 


\title{
APPLYING TOPSIS AND COOPERATIVE GAME THEORY IN AIRLINE MERGING AND COALITION DECISIONS
}

\author{
Oliver F. Shyr* and Yi-Pin Kuo**
}

Keywords: code sharing, airline merging, cooperative games, TOPSIS.

\begin{abstract}
Nowadays, more and more airlines have adopted various alliance strategies, such as code sharing, equity sharing, merging and acquisition to survive in the rigorously competitive market. To assess the effectiveness of code sharing and merging practices among airlines, we include major factors affecting the decisions of code sharing and merging into our model and propose the formulation and calibration procedures of payoff functions under various airline coalition scenarios. In the case study, we apply TOPSIS to assess the importance of factors in the decision making of code sharing and merging and to create a priority ranking of target airlines in the cooperative games. In conclusion, we found that financial stability and profitability are the top two factors affecting merging decision while profitability is the only concern in the code sharing games. In addition, we found that Taiwan's domestic airlines would gain more profits through merging rather than code sharing while EVA and CAL could be the best target for merging.
\end{abstract}

\section{INTRODUCTION}

Since the deregulation of air travel market in Taiwan in 1987, the number of domestic airlines has increased from four to nine. The flight frequency between Taipei and other major cities grew so quickly that the domestic airport in Taipei has become one of the busiest airports in Asia. Consequently, travelers enjoyed the benefits of low airfare and high flight frequency resulted from deregulation

Unfortunately, cut-throat competition among airlines had led to bankruptcy of some airlines and the rising concerns of air safety in the public. To strengthen air travel safety and enhance the competitiveness of domestic airlines, Taiwan's Civil Aviation Bureau (TCAB) released new regulations in 1999 offering incentives for merging among airlines and penalties for

Paper submitted 03/01/06; accepted 02/02/07. Author for correspondence: Oliver F. Shyr (ofshyr@mail.ncku.edu.tw).

* Department of Urban Planning, National Cheng Kung University, Tainan, Taiwan.

** Trans Asia Airways, Taipei, Taiwan those who refused to comply. After a series of merging and acquisitions among airlines, the number of airlines has decreased from nine to six and the cutthroat competition among domestic airlines has come to an end. In the past few years, numerous cases of merging and acquisition among international airlines have been applied to deal with airline bankruptcy. On the other hand, although airline merging is one of the policies promoted by Taiwan aviation authority, little progress has been made after 2000. Taiwan's domestic airlines are more interested in code sharing than merging because the decision regarding merging is much more complicated than the decision regarding code sharing. According to our survey of higher-ranked managers from various airlines, profitability is the primary factor affecting decisions regarding airline code sharing. However, the major factors affecting the decisions regarding airline merging or acquisitions include: 1) the performance of profitability; 2) the financial creditability and stability; 3) the extension of service network; 4) the compatibility of maintenance and logistic systems; and 5) the coordination of human resources. As a result, merging was seldom proposed by domestic airlines and did not draw serious attention to the business unless code sharing was ineffective and the financial condition was further deteriorated. Recently, the issues of airline merging has been raised due to a series of incidents terrorists' attacks on September 11, 2001 targeted on US, a severe China Airline's accident in 2002, and the outbreak of SARS in 2003. During this period, most of Taiwan's airlines have suffered great loss in revenue and patronages for both domestic and international markets. To assess the potential benefits and to find good candidates of merging or acquisitions are now become serious issues for domestic airline managers.

In this study, we first estimate coalition effectiveness by cooperative game approach. Next, we apply multi-criteria decision method, i.e., the Technique for Order Preference by Similarity to Ideal Solution (TOPSIS) developed by Hwang and Yoon [6], to incorporate these factors and provide a priority ranking of target airlines in the practices of code sharing and merging games.

Numerous papers had dealt with airline cooperation issues. Carlton et al. [3] compared the benefits and costs before and after the merging of North Central Airlines and Southern Airways. Their analysis showed that increasing returns to scale 
was probably one of the major incentives for airline merging. Hviid and Prendergast [5] were interested in the bidding game of airline merging. They assumed that the target airline had private information of its own profits, and both the target and the bidder airlines played the Cournot game in a duopolistic market before merging took place. In the equilibrium, the bidder's offer would be rejected only if the operating costs of the target airline were lower than the bidder's expectation. Youssef and Hansen [19] found that code-sharing agreement between Swissair and Scandinavian Airlines System (SAS) had produced higher load factor resulted from better quality of service for customers. Oum et al. [11] developed an analytical procedure for the impact assessment of code sharing between follower and leader airlines. They found that if the follower airlines formed a code-sharing alliance, the leader airline would have to lower airfares in response to the new alliance. In the equilibrium, the leader would have higher load factor due to lower airfares. Furthermore, Park [13] pointed out that code sharing could result in higher consumer's surplus if airlines in the same alliance had similar quality of service with low flight frequency on their routes. Chen [4] studied the merging of China Airline (CAL) and Formosa Airline by analyzing financial data to explore the relationship among bidding prices, financial stability, and profitability. Ko [8] predicted airline's benefits from parallel code sharing cooperation by using travelers' revealed and stated preference data in discrete choice demand modeling. He then applied cooperative game approach to solve the benefit distribution problem of domestic airlines. Agusdinata and de Klein [1] explained the dynamic of airline alliances. Using a system of dynamic approach they described the driving forces behind the formation of alliances internally and externally. Their paper aimed at solutions not only for airlines that are looking for an appropriate alliance group but also for established groups looking for new members. Suen [16] argued that Swissair Group's bankruptcy is a direct consequence of mistakes made in implementing its alliance strategy. While the strategy was sound, her analysis showed that Swissair did not need equity to bind its partners to it. Her approach suggested that the alliance strategy undermined a corporate goal to diversify risk beyond the airline business. Financial analysis showed that airline investment was unprofitable which increased the Group's leverage and weakened its cash position. As a result, the Group did not have adequate resources to recover from external shocks. Although global airline alliances in the 1980s gave rise to concerns that increased monopoly power of major carriers would lead to large and sustained producer surpluses, Morrish and Hamilton [10] examined 15 years of alliance experience and found no conclusive evidence that alliance membership had yielded monopoly profits to the airlines. They found that airline alliances had improved load factors and productivity and yet only produced modest gains to the carriers due to fare restrictions. Shyr and Chang [15], following Ko's approach, compared the customer's surplus before and after international airline's complementary code sharing. Iatrou and Alamdari [7] addressed the perceived impacts of alliances based on a comprehensive survey of the alliance management department. They evaluated the impacts of traffic, load factors, costs, revenues and fares resulted from various forms of alliances. Their analysis showed that each of the four global alliances groupings has experienced different results according to the type of collaboration agreed amongst their member airlines.

As for the applications of decision theory, Pen [14] integrated the theory of competitiveness and Multiple Attribute Decision Making to establish a model comparing airline competitiveness between the year 1992 and 1997. Pen defined the components of competitiveness index as management ability, price competitiveness, service quality, productivity, and cost competitiveness. Using Entropy method for Weighted Product Method (WPM) and TOPSIS methods, Pen concluded that service quality and management ability are two critical indices that are highly related to airline's competitiveness and profitability.

This study applies TOPSIS method to analyze managers' preferences on code sharing and merging for two reasons: 1) TOPSIS is derived from managers' judgments and is effective in many empirical works; 2) with managers' judgments data, we are able to calibrate the priority ranking of various coalition alternatives regarding merging or code sharing.

\section{FORMULATION OF AIRLINE'S PAYOFF FUNC- TION}

\section{Assumptions}

The assumptions of the study are as follows:

1) All domestic airlines are candidates of targets or bidders in the merging games;

2) Code sharing or merging is subject to super-additive assumptions;

3) Decision regarding code sharing or merging is rational;

4) All domestic airfares are restricted to upper limits set by civil aviation authority to maximize social welfares.

The first assumption addresses the fact that all domestic airlines would not give up any good opportunities in the merging games. The second assumption states that airlines would consider code sharing or merging as their feasible options only if they could benefit from these practices, which is the super-additive assumption of cooperative games. The third assumption describes the fact that the practices of code sharing or merging should be driven by the motivation of profit maximization. The last assumption reveals the fact that in many countries domestic airfares are often restricted to upper limits which lead to the maximization of social welfares - the sum of consumer surplus and producer surplus, set by the policy makers of transport authorities. 


\section{Payoff Functions}

The payoff function that could be used for various coalition relationships consists of an air travel demand function of any O-D pair, an airline's load factor function, and a cost function that could reveal different cooperation scenarios. The specification of payoff function is as follows:

$$
\pi_{i j k}=p_{i j k} \cdot q_{i j k}-\cos t_{i j k} \cdot F_{i j k}
$$

Where $\pi_{i j k}$ is the profit of airline alliance k generated from the (i, j) O-D pair, $p_{i j k}$ is the average airfare set by airline alliance $\mathrm{k}$ on the service route of the (i, j) O-D pair, $q_{i j k}$ is the air travel demand of airline alliance $k$ on the service route of the (i, j) O-D pair, Cost $t_{i j k}$ is the cost per flight of airline alliance $\mathrm{k}$ on the service route of the (i, j) O-D pair, $F_{i j k}$ is the flight frequency of airline alliance $k$ on the service route of the (i, j) O-D pair.

\section{Demand and Load Factors}

The air travel demand $q_{i j k}$ is formulated as follows:

$$
\begin{gathered}
q_{i j k}=Q_{i j} \cdot S_{i j k}=F_{i j k} \cdot \text { Seats }_{i j k} \cdot R_{i j k} \\
R_{i j k}=\frac{Q_{i j} \cdot S_{i j k}}{F_{i j k} \cdot S e a t_{i j k}}=\frac{1}{1+e^{-f_{j j k}}} \\
S_{i j k}=\frac{1}{1+\sum_{l \neq k} e^{V_{i j l}-V_{i j k}}}
\end{gathered}
$$

Where, Seat ${ }_{i j k}$ is the number of seats per flight of airline alliance $\mathrm{k}$ of the (i, j) O-D pair, $R_{i j k}$ is the load factor of airline alliance $\mathrm{k}$ of the (i, j) O-D pair, $S_{i j k}$ is the market share of airline alliance $k$ of the (i, j) O-D pair, $V_{i j k}$ is the utility function of passengers choosing airline alliance $k$ of the $(i, j)$ O-D pair, $f_{i j k}$ is the function with attributes related to load factor of airline alliance $\mathrm{k}$ of the (i, j) O-D pair.

The specification of load factor as a logistic function ensures that the value of load factor would lie between 0 and 1 . The utility function of passenger's choice of airline was set to be a linear function of airfares, frequencies, and seasonal adjustment factors. In addition, the load factor model could be calibrated by linear regression approach with the following transformation:

$$
\begin{gathered}
-\ln \left(\frac{1}{R_{i j k}}-1\right)=U_{i j k} \\
=\beta_{0 k}+\beta_{1 k} p_{i j k}+\sum_{l \neq k} \beta_{1 l} p_{i j l}+\beta_{2 k} \ln F_{i j k}+\sum_{l \neq k} \beta_{2 l} \cdot \ln F_{i j l} \\
+\beta_{3 k} F F_{k}+\beta_{4 k} F T_{i j k}+\sum_{l \neq k} \beta_{4 l} F T_{i j l}+\beta_{5 k} D_{1 k}+\beta_{6 k} D_{2 k}+e
\end{gathered}
$$

Where, $p_{i j l}$ is the average airfare set by opponent airline $l$ on the service route of the (i, j) O-D pair, $F_{i j l}$ is the flight frequency of opponent airline $l$ on the service route of the (i, j) O-D pair, $F F_{k}$ is the variable of frequent flyer membership, 1 for the scenario that all passenger are the members of airline $k$, and 0 otherwise. $F T_{i j k}$ is the flight time of airline $k$ on the service route of the $(i, j)$ O-D pair, $F T_{i j l}$ is the flight time of opponent airline $l$ on the service route of the (i, j) O-D pair, $D_{1 \mathrm{k}}$ is the seasonal adjustment factor of airline $k, 1$ for the scenario that the flight departing time is in January, February, April, July, August, December, which are often the months with peak demand, and 0 for other months. $D_{2 \mathrm{k}}$ is the accident adjustment factor of airline alliance $k, 1$ for the scenario of the air travel demand after accidents with high fatality and casualty in the following four months - assuming the negative impacts of major accidents would last for four months, and 0 otherwise. $\beta$ 's is the coefficients of the logistic regression function, and $e$ is the random error.

Because the load factors of airline alliances under various scenarios could not be observed in current practices, we would have to collect survey data of passenger's revealed and stated preferences on airlines. In other words, the load factor function was estimated by using potential demand predicted by the passengers' choice model under various scenarios. Meanwhile, using monthly airlines' load factor data in the past five years, we were able to validate the load factor function with data combination techniques.

\section{Costs}

The cost function consisted of four parts: 1) direct flight costs, i.e., fuel costs; 2) airport holding costs, i.e., landing and holding fees, passengers and cargos logistic costs; 3) variable costs, i.e., passenger service and crew costs; and 4) other costs, i.e., maintenance and leasing costs. It should be noted that the costs vary from code sharing to merging. For instance, code sharing would affect cargo logistic costs, passenger service costs, etc.; merging, on the other hand, would affect crew costs, maintenance and leasing costs if two merging airline reschedule their crews and flights.

\section{SOLUTION APPROACH}

The solution approach consists of four steps: 1) calibrating market shares and estimating payoffs for various carriers; and 2) solving optimal fare rates and daily service frequency under Nash equilibrium; and 3) solving profit distribution problem by using Shapley values; and 4) applying TOPSIS to assess the ranking of factors affecting airlines' merging and the ranking of all coalition alternatives.

\section{Calibration of Payoffs for Various Coalition Strategies}

The calibration begins with the questionnaire survey on 
travelers' preference on choices of airlines under various scenarios. The survey is conducted by general stratified sampling, i.e., the sample should be drawn in proportion to the market shares. The market share model includes all the attributes related to the quality of services and airfares. The functional form of the utility function is usually assumed to be linear. In addition, alternative-specific constants are often specified in the utility function to reveal qualitative characteristics of the services provided by the carriers.

\section{Solution Approach of Nash Equilibrium}

The solution of Nash Equilibrium is derived from the following procedures: 1) finding the upper bound airfares that satisfy maximum social welfare as shown in Equation (6); and 2) solving the system of maximization problems for all competitors as shown in Equation (7). Equation (6) satisfies the fourth assumption while Equation (7) satisfies the third assumption.

$$
\begin{gathered}
\max _{\overline{\mathbf{P}}} \sum_{i} \sum_{j} \sum_{k} \pi_{i j k}(\overline{\mathbf{P}})+C S_{i j k}(\overline{\mathbf{P}}), C S_{i j k}(\overline{\mathbf{P}})=\int_{\bar{P}_{i j k}}^{W P_{i j k}} q_{i j k}(\mathbf{P}) d P_{i j k}, \\
\bar{P}_{i j k} \geq 0, \forall i, j, k
\end{gathered}
$$

$$
\max _{\mathbf{P}} \pi_{i j k}(\mathbf{P}) \text { subject to } 0 \leq P_{i j k} \leq \bar{P}_{i j k} \quad \forall i, j, k
$$

Where, CS ( ) = the consumer surplus, as a function of airfares, $\bar{P}_{i j k}=$ the upper bound airfare of airline alliance $\mathrm{k}$ set by the authority for $(i, j)$ OD pair, $\mathbf{P}=$ the set of airfares for $(i, j)$ OD pair.

Both Equations (7) and (8) require techniques of non-linear optimization and their first order conditions, as shown in Equations (8) and (9), may have multiple solutions. By applying the computer software named MATHEMATICA [18], we can find feasible solutions of Equations (8) and (9).

$$
\begin{gathered}
\frac{\partial}{\partial \bar{P}_{i j k}} \sum_{i} \sum_{j} \sum_{k}\left[\pi_{i j k}(\overline{\mathbf{P}})+C S_{i j k}(\overline{\mathbf{P}})\right]=0, \quad \forall i, j, k \\
\frac{\partial \pi_{i j k}}{\partial P_{i j k}}=0 \quad \text { subject to } \quad P_{i j k}+s_{i j k}=\bar{P}_{i j k} s_{i j k} \geq 0 \forall i, j, k
\end{gathered}
$$

Another alternative to solve Equation (6) and (7) is to apply the first order Taylor series to the predicted daily revenue passengers $q$ as shown in Equation (10) such that the objective functions in Equations (6) and (7) can be approximated as quadratic functions of airfares and Equations (8) and (9) can be transformed into systems of linear equations.

$$
q_{i j k}(\mathbf{P}) \cong q_{i j k}\left(\mathbf{P}_{0}\right)+\left.\left(\mathbf{P}-\mathbf{P}_{0}\right)^{\prime} \frac{\partial q_{i j k}(\mathbf{P})}{\partial \mathbf{P}}\right|_{\mathbf{P}=\mathbf{P}_{0}}
$$

In the case study, we use the fare rates in 2004 for all competing carriers as the vector of $\mathbf{P}_{0}$ applied to Equation (10).

\section{Solution Approach of Cooperative Games}

To evaluate the contributions of allied members in the cooperative games, we propose the following procedures based on Owen [12].

\section{Step I: List all coalition structures.}

A coalition structure is defined as a partition of all players in the cooperative game. For example, if five airlines are forming various alliances, their coalition structures will be $S=\{1\}$ versus $N-S=\{2,3,4,5\}, S=\{3,4\}$ versus $N-S=\{1,2,5\}$, etc. As a result, there will be $2^{N-1}$ coalition structures.

Step II: Calibrate the payoff functions of all coalition structures.

The payoff functions are calibrated by using the same model as in the non-cooperative game, but the data is collected from travelers' stated preference regarding their new choices of carriers if new alliances among airlines were developed.

Step III: Solve the market equilibrium under all coalition structures.

Based on the assumption of efficiency, a solution of the following systems of equations yields the maximum profit and the optimal fare rates to each coalition structure under market equilibrium, as shown in Equation (11).

$$
\left\{\begin{array}{c}
\frac{\partial \pi_{S}}{\partial P_{S}}=0 \\
\frac{\partial \pi_{N-S}}{\partial P_{N-S}}=0
\end{array}\right\} \forall S \subset N
$$

Similarly, Equation (11) could be solved by the technique of Taylor series approximation.

Step IV: Apply software MATHEMATICA to solve the Shapley value.

Given the payoffs derived from Step III, we could apply MATHEMATICA to compute the Shapley value and solve the profit distribution problem in the case study.

The solution concept of Shapley value is based on the evaluation of the marginal contribution of each member under various coalition scenarios. The formula of Shapley values is as follows: 


$$
\varphi_{i}[v]=\sum_{\substack{T \in N \\ i \in T}} \frac{(t-1) !(n-t) !}{n !}[v(T)-v(T-\{i\})]
$$

where $\varphi_{i}[v]$ is the Shapley value of player $i, v(T)$ is the payoff of coalition $T$ including player $i, \quad v(T-\{i\})$ is the payoff of coalition $T$ excluding player $i, n$ is the number of players in the cooperative game, and $t$ is the number of players in coalition $\mathrm{T}$.

\section{Alternative Rankings by TOPSIS}

Next, TOPSIS was adopted to assess the rankings of factors affecting airlines' merging. These factors included profitability, financial stability, complementary with service network, compatibility with maintenance and logistic systems, and coordination of human resources. A set of weights for theses factors was derived based on the preferences of airline managers. The results were then applied to evaluate various coalition strategies among airlines. The solution approach to TOPSIS is as follows:

Step 1: Normalization of indices

$$
\begin{aligned}
& \bar{X}_{i j}=\frac{\left(X_{i j}-X_{\text {min.j }}\right)}{\left(X_{\text {max. } j}-X_{\text {min. } j}\right)} \\
& V_{i j}=W_{j} \times \overline{X_{i j}} \quad, j=1,2, \cdots n
\end{aligned}
$$

where $X_{i j}$ is the $j^{\text {th }}$ index value for the $i^{\text {th }}$ alternative, $X_{\max . j}=\max \left\{X_{i j}, \forall i\right\}, \quad X_{\min . j}=\min \left\{X_{i j}, \forall i\right\} . \quad \bar{X}_{i j}$ is the normalized index, lies between 0 and $1 . V_{i j}$ is the weighted normalized index value, lies between 0 and 1 , and $W_{j}$ is the weights.

Step 2: Calculation of ideal solutions and negative ideal solutions

$$
\begin{aligned}
A^{*} & =\left\{\left(\max _{i} V_{i j} \mid j \in B\right),\left(\min _{i} V_{i j} \mid j \in C\right) \mid i=1,2, \cdots m\right\} \\
& =\left\{V_{1}^{*}, V_{2}^{*}, \cdots V_{j}^{*}, \cdots V_{n}^{*}\right\} \\
A^{-} & =\left\{\left(\min _{i} V_{i j} \mid j \in B\right),\left(\max _{i} V_{i j} \mid j \in C\right) \mid i=1,2, \cdots m\right\} \\
& =\left\{V_{1}^{-}, V_{2}^{-}, \cdots V_{j}^{-}, \cdots V_{n}^{-}\right\}
\end{aligned}
$$

where $B$ is the set of utility indices and $C$ is the set of cost indices, $A^{*}$ and $A^{-}$are the positive and negative ideal solutions, respectively.
Step 3: Computation of Separation Measure

If the ideal solution is positive for utility indices, then

$$
S_{i}^{+}=\sqrt{\sum_{j=1}^{n}\left(V_{i j}-V_{j}^{*}\right)^{2}} \quad, i=1,2, \ldots . ., m
$$

If the ideal solution is negative for cost indices, then

$$
S_{i}^{-}=\sqrt{\sum_{j=1}^{n}\left(V_{i j}-V_{j}^{-}\right)^{2}} \quad, i=1,2, \ldots . ., m
$$

Step 4: Calculation of Relative Closeness (RC) for various factors or alternatives

$$
R C_{i}=\frac{S_{i}^{-}}{S_{i}^{-}+S_{i}^{+}} \quad 0 \leq R C_{i} \leq 1
$$

If $A_{i}=A^{*}$, then $R C_{i^{*}}=1$; if $A_{i}=A^{-}$, then $R C_{i^{*}}=0$.

Step 5: Creation of priority ranking for various factors or alternatives

From Step 4, we could find the RC values for various factors and coalition alternatives. By ranking the RC's in descending order, we are able to create a priority list of different alternatives for airline coalitions.

\section{CASE STUDY}

For the study of code sharing effects, we selected four destinations, i.e., Bangkok, San Francisco, Sydney, and Amsterdam as shown in Figure 1, for international travelers originated or transferred from Taipei. As for merging, we focused on the assessment of various merging alternatives among domestic airlines - because TCAB would not approve of the merging between Taiwanese and foreign airlines.

The survey data consist of two parts: 1) travelers' stated and revealed preferences, and 2) managers' preferences on merging among domestic airlines. Random sampling was performed at the waiting lines of airport counters for travelers flying from Taipei to four selected destinations. Our sample is consistent with the market shares of airlines serving these routes. Figure 1 shows the airlines that are flying these routes. Currently, Qantas and EVA have code sharing agreement in flying between Taipei and Sydney.

As for the survey design of managers' preferences toward coalitions, our questionnaires provided information regarding estimation of profitability, complementary of service network, and financial conditions under all merging scenarios. In addition, managers were asked to evaluate the compatibility of maintenance and logistic systems, and coordination of human resources before and after coalitions. With information of these five factors, i.e., three evaluated by the questionnaires and two evaluated by themselves, managers were then asked to give their preferences on and their priority on various coalition 


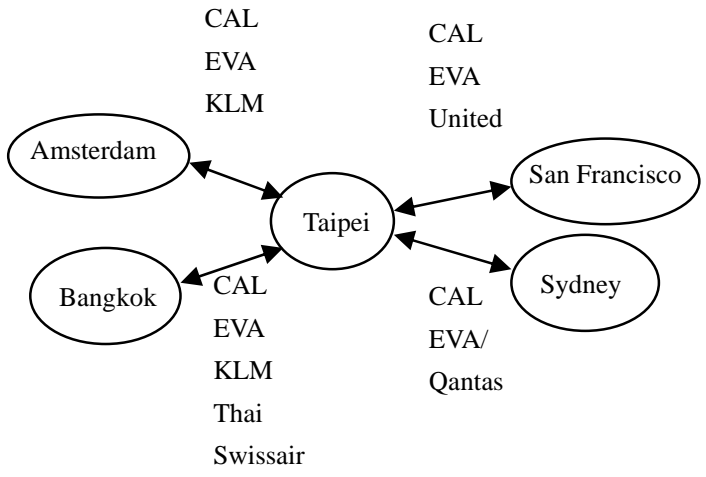

Figure 1. Airlines flying from Taipei to various destinations in the case study.

Table 1. Model parameters of airline's load factor from Taipei to Amsterdam before coalition ( $t$ values in parentheses).

\begin{tabular}{|c|c|c|c|}
\hline $\begin{array}{c}\text { Airline } \\
\text { Variables }\end{array}$ & CAL & EVA & KLM \\
\hline Constant & $\begin{array}{c}7.799 \\
(6.476)\end{array}$ & $\begin{array}{c}12.280 \\
(11.823)\end{array}$ & $\begin{array}{c}12.997 \\
(14.200)\end{array}$ \\
\hline Airfare (CAL) & $\begin{array}{c}-2.354 \\
(-10.041)\end{array}$ & $\begin{array}{c}0.695 \\
(3.435)\end{array}$ & $\begin{array}{c}0.667 \\
(3.741)\end{array}$ \\
\hline Airfare (EVA) & 0.532 & -1.736 & 0.274 \\
$(3.985)$ & $(-15.086)$ & $(2.702)$ \\
\hline Airfare (KLM) & 1.137 & 0.969 & -2.107 \\
& $(5.805)$ & $(5.738)$ & $(-14.154)$ \\
\hline Frequency & 0.542 & -3.872 & -3.337 \\
(CAL) & $(1.250)$ & $(-10.353)$ & $(-10.125)$ \\
\hline $\begin{array}{c}\text { Frequency } \\
\text { (EVA) }\end{array}$ & -1.663 & 1.684 & -1.498 \\
\hline Frequency & $-4.016)$ & $(4.715)$ & $(-4.757)$ \\
(KLM) & $(-6.821)$ & $(-9.528)$ & $(1.716)$ \\
\hline Membership & 5.486 & -1.459 & -1.613 \\
(CAL) & $(7.369)$ & $(-1.615)$ & $(-2.851)$ \\
\hline Membership & -0.421 & 4.656 & -1.112 \\
(EVA) & $(-0.557)$ & $(7.141)$ & $(-1.936)$ \\
\hline $\begin{array}{c}\text { Membership } \\
\text { (KLM) }\end{array}$ & -1.348 & -1.459 & 5.878 \\
$(-1.286)$ & $(-1.615)$ & $(7.381)$ \\
\hline $\begin{array}{c}\text { Seasonal Fac- } \\
\text { tor: D1 }\end{array}$ & -1.329 & -0.201 & 0.09463 \\
\hline $\begin{array}{c}\text { Accident Fac- } \\
\text { tor: D2 }\end{array}$ & -0.481 & -0.444 & -0.565 \\
$(-0.850)$ & $(-0.909)$ & $(-1.314)$ \\
\hline Adjusted $R^{2}$ & 0.710 & 0.903 & 0.904 \\
\hline F Value & 501.713 & 226.250 & 90.229 \\
\hline
\end{tabular}

Note: 33 New Taiwan Dollars (NTD) = 1 US Dollar (USD). Airfares are recorded in $1000 \mathrm{NTD}$ and frequencies are recorded in flights per week.
Table 2. Model parameters of airline's load factor from Taipei to Amsterdam: the case of code sharing between CAL and KLM ( $t$ values in parentheses).

\begin{tabular}{|c|c|c|c|}
\hline $\begin{array}{c}\text { Airline } \\
\text { Variables }\end{array}$ & CAL & EVA & KLM \\
\hline Constant & $\begin{array}{r}8.337 \\
(2.404) \\
\end{array}$ & $\begin{array}{c}5.440 \\
(1.954) \\
\end{array}$ & $\begin{array}{c}16.541 \\
(7.337) \\
\end{array}$ \\
\hline $\begin{array}{c}\text { Airfare } \\
\text { (CAL) }\end{array}$ & $\begin{array}{c}-2.670 \\
(-5.416) \\
\end{array}$ & $\begin{array}{c}0.290 \\
(1.732) \\
\end{array}$ & $\begin{array}{c}0.847 \\
(2.644)\end{array}$ \\
\hline $\begin{array}{c}\text { Airfare } \\
\text { (EVA) }\end{array}$ & $\begin{array}{c}0.385 \\
(1.872) \\
\end{array}$ & $\begin{array}{c}-1.451 \\
(-3.937) \\
\end{array}$ & $\begin{array}{c}1.290 \\
(4.324) \\
\end{array}$ \\
\hline $\begin{array}{l}\text { Airfare } \\
\text { (KLM) }\end{array}$ & $\begin{array}{c}0.858 \\
(1.869)\end{array}$ & $\begin{array}{c}0.251 \\
(1.708)\end{array}$ & $\begin{array}{c}-2.362 \\
(-8.228)\end{array}$ \\
\hline $\begin{array}{c}\text { Frequency } \\
\text { (CAL) }\end{array}$ & $\begin{array}{c}1.855 \\
(3.422) \\
\end{array}$ & $\begin{array}{c}-0.872 \\
(-2.005) \\
\end{array}$ & $\begin{array}{c}-2.416 \\
(-6.857) \\
\end{array}$ \\
\hline $\begin{array}{c}\text { Frequency } \\
\text { (EVA) }\end{array}$ & $\begin{array}{c}-1.178 \\
(-2.399)\end{array}$ & $\begin{array}{c}0.178 \\
(1.417) \\
\end{array}$ & $\begin{array}{c}-3.023 \\
(-8.745)\end{array}$ \\
\hline $\begin{array}{c}\text { Frequency } \\
(\mathrm{KLM})\end{array}$ & $\begin{array}{c}-2.328 \\
(-4.378) \\
\end{array}$ & $\begin{array}{c}-0.917 \\
(-2.326) \\
\end{array}$ & $\begin{array}{c}-1.347 \\
(-4.223) \\
\end{array}$ \\
\hline $\begin{array}{c}\text { Flight time } \\
\text { (CAL) }\end{array}$ & $\begin{array}{c}-0.442 \\
(-3.972) \\
\end{array}$ & $\begin{array}{c}0.242 \\
(2.703) \\
\end{array}$ & $\begin{array}{c}0.329 \\
(4.544) \\
\end{array}$ \\
\hline $\begin{array}{c}\text { Flight time } \\
\text { (EVA) }\end{array}$ & $\begin{array}{c}0.114 \\
(1.023) \\
\end{array}$ & $\begin{array}{c}-0.312 \\
(-3.486) \\
\end{array}$ & $\begin{array}{c}0.203 \\
(2.808) \\
\end{array}$ \\
\hline $\begin{array}{c}\text { Flight time } \\
(\text { KLM) }\end{array}$ & $\begin{array}{c}0.206 \\
(1.848) \\
\end{array}$ & $\begin{array}{c}0.162 \\
(1.819) \\
\end{array}$ & $\begin{array}{c}-0.765 \\
(-10.581) \\
\end{array}$ \\
\hline Adjusted $R^{2}$ & 0.769 & 0.742 & 0.935 \\
\hline F Value & 10.622 & 5.452 & 42.810 \\
\hline
\end{tabular}

Note: flight time is recorded in hours.

alternatives.

\section{Calibration of Load Factors and Costs for Various Coalitions}

Given the fact that historical load factor data for most of the code sharing and merging cases were unavailable, we apply travelers' stated preference data to calibrate airline's market share as multinomial Logit models. Then, we produce the stated preference load factor data with the prediction drawn from the stated-preference market share models. By applying data combination technique [2] to the stated preference and the revealed preference load factor data - the historical data, we produce the results of model calibration as shown in Table 1.

In the paper, we only present the estimated results based on the travel data from Taipei to Amsterdam. Detail results could be found in the theses written by Kuo [9], Shyr and Chang [15]. Table 2 shows the estimation results for the code sharing between CAL and KLM. Table 3 shows the results for the merging of CAL and EVA.

Except for the insignificant signs of seasonal factor, most of the estimated parameters are consistent with our a priori. For instance, the signs for airfares, opponents' frequency, and ac- 
Table 3. Model parameters of airline's load factor from Taipei to Amsterdam: the case of merging between CAL and EVA ( $t$ values in parentheses).

\begin{tabular}{|c|c|c|}
\hline $\begin{array}{c}\text { Airline } \\
\text { Variables }\end{array}$ & CAL and EVA & KLM \\
\hline Constant & $\begin{array}{c}7.258 \\
(4.025)\end{array}$ & $\begin{array}{c}11.077 \\
(2.222)\end{array}$ \\
\hline $\begin{array}{c}\text { Airfare } \\
\text { (CAL/EVA) }\end{array}$ & $\begin{array}{c}-1.078 \\
(-3.595)\end{array}$ & $\begin{array}{c}1.641 \\
(1.979)\end{array}$ \\
\hline $\begin{array}{c}\text { Airfare } \\
\text { (KLM) }\end{array}$ & $\begin{array}{c}0.127 \\
(1.347)\end{array}$ & $\begin{array}{c}-2.124 \\
-2.102)\end{array}$ \\
\hline $\begin{array}{c}\text { Frequency } \\
\text { (CAL/EVA) }\end{array}$ & $\begin{array}{c}-1.425 \\
(-3.623)\end{array}$ \\
\hline Frequency & -1.326 & -1.876 \\
(KLM) & $(-3.929)$ & $(-2.010)$ \\
\hline Adjusted $R^{2}$ & 0.824 & 8.007 \\
\hline F Value & 10.394 & \\
\hline
\end{tabular}

cident are negative in both Table 2 and Table 3; and the signs of frequency and opponents' airfares are positive in Table 2. To explain why the signs of frequency in Table 3 are negative, we need to verify that the demand of air travel has a property of decreasing returns of scales.

Judging from the magnitudes of the parameters shown in Table 2, we find that airline's flight frequency has positive but smaller effects on its own load factor, while it has negative but larger effects on its opponent's load factor. If one airline merged with one of its opponents, the load factor of the merged airline would decrease as flight frequency increases resulted from merging. In conclusion, the calibrated results are consistent with the property of decreasing returns of scales.

As for the calibration of cost functions, we used Boeing $747-400$ as an example for the demonstration. Table 4 shows the total operating costs per flight from Taipei to four destinations in the pre-coalition case based upon the data provided by Tseng [17]. We further assume that the estimated operating costs per flight remain the same before and after code sharing while the costs per flight are deducted $15 \%$ after merging because we assume that merging could save some indirect operation costs, i.e., management cost, advertisement cost, promotion costs, etc. The assumption of cost reduction is based on the fact that the information regarding merging are often very confidential and it may vary from one case to another, depending on the number of lay-off workers. Therefore, our best guess of cost reduction would be the ratio of indirect operation costs to the total operation costs.

\section{Case of International Airlines - Assessment of Code Sharing}

In the following sections, we present the cases of parallel and complementary code sharing between Taiwanese and Foreign
Table 4. Estimated operating costs for each flight from Taipei to four destinations.

\begin{tabular}{|c|c|c|c|c|}
\hline $\begin{array}{c}\text { Destination } \\
\text { Category }\end{array}$ & Amsterdam & $\begin{array}{c}\text { San Fran- } \\
\text { cisco }\end{array}$ & Sydney & Bangkok \\
\hline $\begin{array}{c}\text { Direct Flight } \\
\text { Distance (km) }\end{array}$ & 9436.16 & 10384.25 & 7280.52 & 2487.53 \\
\hline $\begin{array}{c}\text { Fuel Costs } \\
\text { \$NTD }\end{array}$ & $1,594,573$ & $1,359,918$ & $1,145,968$ & 309,131 \\
\hline $\begin{array}{c}\text { Holding Costs } \\
\text { \$NTD }\end{array}$ & 378,703 & 325,227 & 310,781 & 259,490 \\
\hline $\begin{array}{c}\text { Other Costs } \\
\text { \$NTD }\end{array}$ & 393,844 & 330,077 & 325,227 & 116,760 \\
\hline Total \$NTD & $2,090,036$ & $2,015,222$ & $2,781,976$ & 685,381 \\
\hline
\end{tabular}

Table 5. Optimal airfares, load factors, and weekly profits before coali-

\begin{tabular}{|c|c|c|c|c|c|}
\multicolumn{1}{c|}{ iion. } \\
$\begin{array}{c}\text { Origin/ } \\
\text { Destination }\end{array}$ & Airlines & $\begin{array}{c}\text { Weekly } \\
\text { Flights }\end{array}$ & $\begin{array}{c}\text { Airfares } \\
\text { in \$NTD }\end{array}$ & $\begin{array}{c}\text { Load } \\
\text { Factor }\end{array}$ & $\begin{array}{c}\text { Weekly Profits } \\
\text { in \$NTD }\end{array}$ \\
\hline \multirow{3}{*}{$\begin{array}{c}\text { Taipei/ } \\
\text { Amsterdam }\end{array}$} & CAL & 7 & 36,724 & $69 \%$ & $47,802,675$ \\
\cline { 2 - 7 } & EVA & 4 & 38,048 & $70 \%$ & $28,681,838$ \\
\cline { 2 - 7 } & KLM & 7 & 39,634 & $77 \%$ & $57,599,006$ \\
\hline \multirow{3}{*}{$\begin{array}{c}\text { Taipei/ } \\
\text { Sydney }\end{array}$} & CAL & 3 & 27,260 & $85 \%$ & $12,058,972$ \\
\cline { 2 - 7 } & EVA & 2 & 20,860 & $88 \%$ & $7,919,348$ \\
\cline { 2 - 6 } & QAN & 2 & 22,832 & $88 \%$ & $9,286,548$ \\
\hline
\end{tabular}

airlines on four international routes, i.e., from Taipei to Sydney, Bangkok, San Francisco, and Amsterdam. For the cases of parallel code sharing, i.e., allied airlines flying on the same routes, travel demands and estimated profits were evaluated based on one way trips from Taipei to Sydney and to Amsterdam. For the case of complementary code sharing, i.e., allied airlines providing transfer connections on separate routes, travel demands and estimated profits were evaluated based on one way trips from Taipei to Bangkok and to San Francisco, plus the transfer trips from Bangkok to San Francisco.

\section{1) Payoffs for Parallel Code Sharing}

Based on the estimated costs as shown in Table 4 and the calibrated load factor model as shown in Table 1, Table 2, and Table 3, we apply software Mathematica (Varian [18]) to solve the optimal airfares in the Bertrand games. The results before and after various coalition cases for flights from Taipei to Amsterdam and to Sydney are shown in Table 5 and Table 6.

In Table 6, all the cases of code sharing were evaluated based on transfer time within two hours. In comparison of these Tables, we find that for the allied members, their load factors are higher and their airfares are lower in the case of merging between CAL and EVA and the cases of code sharing among airlines than the cases before coalition. The results are consistent with Park's findings [13]. In addition, according to 
Table 6. Optimal airfares, load factors, and weekly profits after coalition.

\begin{tabular}{|c|c|c|c|c|c|c|}
\hline Destination & \multicolumn{2}{|c|}{ Scenario } & Airlines & $\begin{array}{c}\text { Airfares } \\
\text { in } \\
\text { \$NTD }\end{array}$ & $\begin{array}{l}\text { Load } \\
\text { Factor }\end{array}$ & $\begin{array}{l}\text { Weekly } \\
\text { Profits in } \\
\text { \$NTD }\end{array}$ \\
\hline \multirow{11}{*}{ Amsterdam } & \multirow{9}{*}{$\begin{array}{c}\text { Parallel } \\
\text { Code } \\
\text { Sharing }\end{array}$} & \multirow{3}{*}{ CAL/EVA } & CAL & 27,905 & $87 \%$ & $47,501,900$ \\
\hline & & & EVA & 30,035 & $85 \%$ & $53,916,300$ \\
\hline & & & KLM & 25,535 & $74 \%$ & $37,024,600$ \\
\hline & & \multirow{3}{*}{ CAL/KLM } & CAL & 26,406 & $86 \%$ & $42,969,477$ \\
\hline & & & EVA & 24,769 & $72 \%$ & $19,240,338$ \\
\hline & & & KLM & 30,801 & $86 \%$ & 49,923,309 \\
\hline & & \multirow{3}{*}{ EVA/KLM } & CAL & 43,519 & $91 \%$ & $83,032,700$ \\
\hline & & & EVA & 41,420 & $91 \%$ & $74,156,300$ \\
\hline & & & KLM & 31,288 & $87 \%$ & $53,502,900$ \\
\hline & \multirow{2}{*}{ Merging } & \multirow{2}{*}{ CAL/EVA } & CAL/EVA & 32,558 & $72 \%$ & $72,856,154$ \\
\hline & & & KLM & 30,279 & $85 \%$ & $48,410,644$ \\
\hline \multirow{11}{*}{ Sydney } & \multirow{9}{*}{\begin{tabular}{|c} 
Parallel \\
Code \\
Sharing
\end{tabular}} & \multirow{3}{*}{ CAL/EVA } & CAL & 33,217 & $79 \%$ & $14,714,672$ \\
\hline & & & EVA & 24,215 & $78 \%$ & $8,353,648$ \\
\hline & & & QAN & 28,074 & $83 \%$ & $11,699,248$ \\
\hline & & \multirow{3}{*}{ CAL/QAN } & CAL & 38,637 & $79 \%$ & $18,266,672$ \\
\hline & & & EVA & 24,249 & $73 \%$ & $7,428,148$ \\
\hline & & & QAN & 24,959 & $72 \%$ & $7,702,448$ \\
\hline & & \multirow{3}{*}{ EVA/QAN } & CAL & 30,500 & $79 \%$ & $12,838,072$ \\
\hline & & & EVA & 22,151 & $74 \%$ & $6,517,348$ \\
\hline & & & QAN & 26,960 & $82 \%$ & $10,846,448$ \\
\hline & \multirow{2}{*}{ Merging } & \multirow{2}{*}{ CAL/EVA } & CAL/EVA & 32,168 & $70 \%$ & $32,666,100$ \\
\hline & & & QAN & 29,910 & $85 \%$ & $12,531,700$ \\
\hline
\end{tabular}

Table 6 we found that the profit of code sharing between KLM and CAL is less than the profit of KLM profit plus the profit of CAL before coalition. Similarly, the profit of merging between CAL and EVA is also less than the profit of EVA plus the profit of CAL before coalition. In other words, the estimated profits did not increase because of code sharing or merging. Unless the costs could be significantly reduced in cases of code sharing or merging, airlines flying from Taipei to Amsterdam would have no incentive for code sharing or merging.

\section{2) Payoffs for Complementary Code Sharing}

As to complementary code sharing, currently both CAL and EVA provide direct services from Bangkok to San Francisco with transfer at Taipei. To provide the same services, United Airline must be code sharing with Thai Airways, KLM, or Swissair. In this case, we assume that all these six airlines are the players of the game, and United Airline could be simultaneously code sharing with more than one airline in competing with CAL and EVA. Table 7 shows the estimated profits and
Table 7. Optimal airfares in Bertrand game: the case of complementary code sharing from Bangkok to San Francisco.

\begin{tabular}{|c|c|c|c|c|c|}
\hline Airlines & $\begin{array}{c}\text { Transfer } \\
\text { Time in } \\
\text { Hours }\end{array}$ & $\begin{array}{c}\text { Airfares in } \\
\text { \$NTD }\end{array}$ & $\begin{array}{c}\text { Market } \\
\text { Share \% }\end{array}$ & $\begin{array}{c}\text { Weekly } \\
\text { Profits in } \\
\text { \$NTD }\end{array}$ & $\begin{array}{c}\text { Consumers' } \\
\text { Surplus in } \\
\text { \$NTD/week }\end{array}$ \\
\hline CAL & 0.83 & 18,053 & $12 \%$ & $2,579,927$ & 18,138 \\
\hline EVA & 1.5 & 16,891 & $9 \%$ & $1,440,495$ & 13,022 \\
\hline United-Thai & 1.5 & 18,312 & $8 \%$ & $2,023,385$ & 13,961 \\
\hline United-KLM & 0.67 & 11,977 & $36 \%$ & $3,772,755$ & 31,651 \\
\hline United-Swissair & 1 & 11,574 & $35 \%$ & $3,450,132$ & 29,739 \\
\hline
\end{tabular}

optimal airfares for complementary code sharing of flights from Bangkok to San Francisco.

The computation of Shapley values were derived from the following coalition structures:

1) Players: CAL (C), EVA(E), United (U), Thai (T), KLM (K), and Swissair (S);

2) Dummy Coalitions: no complementary code sharing could be formed by the members, for example, $\{\mathrm{C}, \mathrm{E}\},\{\mathrm{T}, \mathrm{K}, \mathrm{S}\}$, etc.; in these cases, the payoffs are zeros.

3) Effective Coalitions: complementary code sharing could be formed by the members, for example, $\{U, T\},\{U, K, S\}$, $\{\mathrm{U}, \mathrm{T}, \mathrm{K}, \mathrm{S}\}$, etc.; in these cases, the payoffs are the profits of code sharing between United Airline and other airlines except CAL and EVA.

4) Hybrid Coalitions: complementary code sharing could be formed by part of the members, for example, $\{C, U, T\},\{E$, $\mathrm{U}, \mathrm{K}$ \}, etc.; in these cases, CAL and EVA are dummy members in the coalitions.

Table 7 provides the estimated payoff of $\{U, T, K, S\}$, while the estimated payoffs of other coalitions could be found in the paper written by Shyr and Chang [15]. From Table 7, we learn that the code sharing among United Airline, Thai Airways, KLM, and Swissair would decrease the market shares of CAL and EVA significantly. In most cases, the code sharing of United and the other airlines could provide lower airfares with less transfer time to attract passengers flying from Bangkok to San Francisco who are used to choose the direct flight services provided by CAL and EVA.

By applying software MATHEMATICA, we compute the Shapley values for six players as shown in Table 8. In other words, Table 8 provides the profit distributions of complementary code sharing among United Airline, Thai Airways, KLM, and Swissair.

By applying software MATHEMATICA, we compute the Shapley values for six players as shown in Table 8. In other words, Table 8 provides the profit distributions of complementary code sharing among United Airline, Thai Airways, KLM, and Swissair.

If United Airline is allowed to code sharing with one airline only, then the profit split could be derived from Table 7 to 
Table 8. Shapley values of code sharing for Bangkok-San Francisco flights.

\begin{tabular}{|c|c|c|c|c|c|c|}
\hline Airline & CAL & EVA & United & Thai & KLM & Swissair \\
\hline Shapley Values & 0 & 0 & 223,643 & 16,466 & 148,991 & 5,051 \\
\hline \% Share & 0 & 0 & $56.74 \%$ & $4.18 \%$ & $37.80 \%$ & $1.28 \%$ \\
\hline
\end{tabular}

Table 9. Effects of code sharing and profit splits for Bangkok-San Francisco flights.

\begin{tabular}{|c|c|c|c|c|c|c|c|}
\hline \multirow{2}{*}{ Scenarios } & \multicolumn{3}{|c|}{ Profits (\$NTD) } & \multicolumn{4}{|c|}{ Profit Splits (\$NTD) } \\
\cline { 2 - 8 } & Before & After & Change & United & Thai & KLM & Swissair \\
\hline United-Thai & $1,805,930$ & $1,905,030$ & $+129,100$ & 120,247 & 8,853 & 0 & 0 \\
\hline United-KLM & $3,592,350$ & $3,986,500$ & $+394,150$ & 236,556 & 0 & 157,594 & 0 \\
\hline $\begin{array}{c}\text { United- } \\
\text { Swissair }\end{array}$ & $4,413,320$ & $4,473,930$ & $+60,610$ & 59,271 & 0 & 0 & 1,339 \\
\hline
\end{tabular}

Table 10. The estimated profits before and after code sharing or merg-

ing.
\begin{tabular}{|c|c|c|c|c|c|}
\hline \multirow{2}{*}{ Airlines } & \multicolumn{5}{|c|}{ Airlines } \\
\cline { 2 - 7 } & CAL & EVA & FAT & TRA & UNA \\
\hline CAL & $1,325,142$ & 199,010 & - & - & - \\
\hline EVA & $19,223,718$ & $2,136,313$ & - & - & - \\
\hline FAT & - & - & $1,330,104$ & $2,264,967$ & $3,239,363$ \\
\hline TRA & - & - & $5,234,160$ & 806,657 & $2,659,184$ \\
\hline UNA & - & - & $7,245,740$ & $5,550,520$ & $1,725,899$ \\
\hline
\end{tabular}

produce the profit splits as shown in Table 9. From Table 7, Table 8, and Table 9, we learned that the code sharing between United Airline and KLM would generate not only the maximum profits but also the largest consumers' surplus among all scenarios. As a result, United Airline and KLM have the largest Shapley values as well as the largest shares of coalition profits.

\section{3) Case of Domestic Airlines - Priority Ranking of Coali- tions by TOPSIS}

As mentioned above, merging between domestic Airlines and foreign Airlines is not allowed in Taiwan, so we could only show the merging of domestic airlines in the case study. Table 10 shows the estimated profit changes after code sharing and merging from sample routes for five Taiwanese airlines, i.e., China Airlines (CAL), EVA Air (EVA), Far Eastern Air Transport (FAT), Trans Asia Airways (TRA), and UNI Air (UNA). In Table 10, figures in the diagonal section represent the profits before code sharing, figures in the upper triangular area are the additional profits derived from code sharing, and figures in the lower triangular area are the additional profits derived from merging. The estimations of profit changes are based on the calibration results provided by Kuo [9]. Currently, CAL and EVA provide international services while FAT, TRA, and UNA
Table 11. Financial data for Taiwan's major airlines.

\begin{tabular}{|c|c|c|c|c|c|c|}
\hline \multirow{2}{*}{\multicolumn{2}{|c|}{ Category }} & \multicolumn{5}{|c|}{ Airlines } \\
\hline & & CAL & EVA & FAT & TRA & UNA \\
\hline \multirow[b]{2}{*}{$\begin{array}{l}\text { Financial } \\
\text { Structure }\end{array}$} & $\begin{array}{c}\text { Debt Asset } \\
\text { Ratio }\end{array}$ & 69.89 & 74.00 & 71.26 & 66.02 & 84.88 \\
\hline & $\begin{array}{c}\text { Long Term } \\
\text { Capital and } \\
\text { Fixed Asset } \\
\text { Ratio }\end{array}$ & 105.13 & 137.00 & 136.45 & 89.12 & 83.29 \\
\hline \multirow{3}{*}{$\begin{array}{c}\text { Liquidity } \\
\text { Ratio }\end{array}$} & Current Ratio & 78.22 & 74.00 & 102.10 & 32.31 & 56.88 \\
\hline & Quick Ratio & 44.88 & 38.00 & 67.98 & 20.09 & 21.28 \\
\hline & $\begin{array}{l}\text { Times- } \\
\text { Interest- } \\
\text { Earned }\end{array}$ & 140.15 & 9 & NA & $0.54 *$ & $0.82 *$ \\
\hline \multirow{4}{*}{$\begin{array}{c}\text { Asset Man- } \\
\text { agement } \\
\text { Ratio }\end{array}$} & $\begin{array}{c}\text { Account Re- } \\
\text { ceivable Turn- } \\
\text { over Rate }\end{array}$ & 12.59 & NA & 34.46 & 18.99 & 26.25 \\
\hline & $\begin{array}{c}\text { Average Col- } \\
\text { lection Period } \\
\text { (days) }\end{array}$ & 28.99 & NA & 10.59 & 19.23 & 14 \\
\hline & $\begin{array}{c}\text { Fixed Asset } \\
\text { Turnover Ratio }\end{array}$ & 0.60 & 0.84 & 0.64 & 0.90 & 0.63 \\
\hline & $\begin{array}{c}\text { Total Asset } \\
\text { Turnover Ratio }\end{array}$ & 0.47 & 0.46 & 0.41 & 0.59 & 0.33 \\
\hline \multirow{5}{*}{$\begin{array}{c}\text { Profitability } \\
\text { Ratio }\end{array}$} & $\begin{array}{c}\text { Return on } \\
\text { Assets }\end{array}$ & 3.38 & NA & $5.08 *$ & $2.04 *$ & $5.82 *$ \\
\hline & $\begin{array}{l}\text { Return on } \\
\text { Equity }\end{array}$ & 4.09 & $10.0^{*}$ & $23.64 *$ & $20.03 *$ & $95.07^{*}$ \\
\hline & $\begin{array}{c}\text { Basic Earning } \\
\text { Power Ratio }\end{array}$ & 6.77 & $15.0 *$ & $21.28 *$ & $9.49 *$ & 168.95* \\
\hline & $\begin{array}{c}\text { Profit Margin } \\
\text { on Sales }\end{array}$ & 2.55 & $6.00 *$ & $19.24 *$ & $10.1^{*}$ & $30.26 *$ \\
\hline & $\begin{array}{c}\text { Earnings per } \\
\text { Share (\$NTD) }\end{array}$ & 0.74 & $1.44^{*}$ & $2.12^{*}$ & $1.08 *$ & $15.39 *$ \\
\hline \multirow{3}{*}{$\begin{array}{c}\text { Cash Flow } \\
\text { Management }\end{array}$} & $\begin{array}{c}\text { Cash Flow } \\
\text { Ratio } \\
\end{array}$ & 23.90 & 2.00 & 106.57 & 3.33 & $8.22 *$ \\
\hline & $\begin{array}{c}\text { Affordable } \\
\text { Cash Flow } \\
\text { Ratio } \\
\end{array}$ & 16.79 & 43.00 & 19.10 & 8.64 & $35.04 *$ \\
\hline & $\begin{array}{c}\text { Cash Rein- } \\
\text { vestment Ratio }\end{array}$ & 2.34 & NA & 6.88 & 1.32 & $5.79 *$ \\
\hline \multirow{2}{*}{ Leverage } & $\begin{array}{l}\text { Operating } \\
\text { Leverage }\end{array}$ & 3.28 & 125.16 & NA & NA & $3.09 *$ \\
\hline & $\begin{array}{c}\text { Financial Lev- } \\
\text { erage }\end{array}$ & $4.31 *$ & $0.10^{*}$ & NA & NA & 0.48 \\
\hline
\end{tabular}

Note: NA for Not Available; figures shown in $(*)$ are estimated values.

fly to most of the domestic destinations with very limited international services. With limited coalition information provided by sample routes, we learned that code sharing between FAT and UNA might be the best choice among all code sharing alternatives while merging of CAL and EVA could produce the largest profits in all coalition alternatives. In addition, Table 10 shows that airlines would produce more profits in all cases of 
Table 12. Ranking of merging preferences.

\begin{tabular}{|c|c|c|}
\hline Target $\backslash$ Bidder & CAL & FAT \\
\hline CAL & NA & 2 \\
\hline EVA & 1 & 1 \\
\hline FAT & 4 & NA \\
\hline TRA & 3 & 4 \\
\hline UNA & 2 & 3 \\
\hline
\end{tabular}

Table 13. Ranking of domestic airline's preferences on coalition alternatives.

\begin{tabular}{|c|c|c|c|}
\hline $\begin{array}{c}\text { Alternative } \\
\text { Airlines }\end{array}$ & $\begin{array}{c}\text { Far Eastern } \\
\text { Air }\end{array}$ & $\begin{array}{c}\text { Trans } \\
\text { Asia }\end{array}$ & Uni Air \\
\hline No Coalition & 5 & 5 & 5 \\
\hline Code Sharing with FAT & - & 3 & 3 \\
\hline Code Sharing with TRA & 3 & - & 4 \\
\hline Code Sharing with UNI & 3 & 4 & - \\
\hline Merging with FAT & - & 1 & 1 \\
\hline Merging with TRA & 1 & - & 2 \\
\hline Merging with UNA & 2 & 2 & - \\
\hline
\end{tabular}

coalitions than the cases without coalition.

Table 11 shows the financial performances of 2001 provided by five domestic airlines. The financial data of CAL, EVA, and FAT are provided by Taiwan Stock Exchange cooperation while the financial data of UNA and TRA are provided by TCAB.

From Table 11, we learn that earn per share (EPS) of CAL is not the highest in Taiwan's airline industry, but the stock exchanging value of CAL is often the highest among the three. Because CAL has always been the largest airline in Taiwan, it is often the bidder in the merging games.

From the weights of five factors affecting airline merging calibrated by TOPSIS, we find that financial stability is the major concern in merging decision, followed by profitability, network coverage, maintenance compatibility, and human coordination. The results are consistent with the fact that CAL or EVA often plays as bidder in the airline merging games.

If we assume that CAL and FAT were the bidders, their preferences on merging targets are shown in Table 12. Based on our analysis, we conclude that the best target for CAL would be EVA, and its second choice would be UNA. Likewise, the best target for FAT is EVA, and its second choice would be CAL. The choices are consistent with the fact that CAL, EVA, and UNA have good performance on financial stability and profitability over the past decade.

For other domestic airlines, the ranking of coalition alterna- tives are shown in Table 13. From Table 13 we learn that: 1 ) code sharing would be less attractive than merging for FAT, TRA, and UNA; 2) FAT is the best target for TRA and UNA in the merging games; 3 ) the worst alternative would be no coalition with any other airlines. In other words, all the domestic airlines are willing to merge or be merged to enhance their market shares and profitability in the highly competitive market.

\section{CONCLUSION}

The major findings of our paper are summarized as follows:

1) Our analysis suggests that merging of CAL and EVA or code sharing among airlines would result in lower airfares and higher load factors for all airlines flying from Taipei to Amsterdam and to Sydney. The results are consistent with Park's findings which suggest that international flights may not benefit from parallel code sharing unless the costs could be significantly reduced.

2) The complementary code sharing between United Airline and KLM may produce not only the maximum profits but also the largest consumer surplus due to lower airfares and less transfer time. In other words, for passengers flying from Bangkok to San Francisco, the code sharing of United and KLM is very attractive in comparison with the direct flight services provided by CAL and EVA. As a result, the market shares of CAL and EVA would drop significantly for flights between Bangkok and San Francisco.

3) By analyzing the Shapley Values of all airlines and the changes in consumer surplus, we are able to evaluate the impacts of strategic alliances and merging on both airlines and passengers. And we find that airlines with the capability to produce the maximum profits among all coalition scenarios would have the highest Shapley values.

4) Based on our TOPSIS analysis, we find that the most important factors affecting airline coalition are profitability and financial credibility and stability. The results are consistent with the fact that CAL or EVA often plays as bidder in the airline merging games.

5) If we assume that CAL and FAT are the bidders, their preferences on merging targets suggest that the best target for CAL would be EVA, and its second choice would be UNA. Likewise, the best target for FAT is EVA, and its second choice would be CAL. The choices are consistent with the fact that CAL, EVA, and UNA have good performance on financial stability and profitability over the past decade.

6) Domestic Taiwanese airlines would gain more profits through merging rather than code sharing, and airlines might produce more profits in all the cases of airline coalitions than the cases with no coalition. 


\section{REFERENCES}

1. Agusdinata, B. and de Klein, W., "The Dynamic of Airline Alliances," Journal of Air Transport Management, Vol. 8, pp. 201-211 (2002).

2. Ben-Akiva, M. and Lerman, S., Discrete Choice Analysis, MIT Press, Cambridge, MA (1985).

3. Carlton, D. W., Landes, W. M., and Posner, R. A., "Benefits and Costs of Airline Mergers: A Case Study,” Bell Journal of Economics, Vol. 11, No. 1, pp. 65 (1980).

4. Chen, Y. H., "Research on the Integrated Management after M\&A--Take China Airline for Example,” MBA Thesis, National Chen-Chi University, Taiwan (1999).

5. Hviid, M., and Prendergast C., "Merger Failure and Merger Profitability," The Journal of Industrial Economics, Vol. 41, No. 4, pp. 371, (1993).

6. Hwang, C. L. and Yoon, K., Multiple Attribute Decision Making: Methods and Applications, Springer-Verlag Publishers (1981).

7. Iatrou, K. and Alamdari, F., "The Empirical Analysis of the Impact of Alliances on Airline Operations," Journal of Air Transport Management, Vol. 11, pp. 127-134 (2005).

8. Ko, Y. L., "Modeling Airline Competition with Alliances as Cooperative Games," Master Thesis, Department of Transportation Management, Tamkang University, Taiwan (1999).

9. Kuo, Y. P., "Modeling Airline Merger: Evaluation and Decision Making”, Master Thesis, Department of Transportation Management, Tamkang University, Taiwan (2003).

10. Morrish, S. C. and Hamilton, R. T., "Airline Alliances - Who Benefits?"
Journal of Air Transport Management, Vol. 8, pp. 401-407 (2002).

11. Oum, T. H., Zhang, A., and Zhang, A., "The Effects of Airline Code Sharing Agreement on Firm Conduct and International Airfares," Journal of Transport Economics and Policy, Vol. 30, No. 2, pp. 187-202 (1996).

12. Owen, G., Game Theory -Second Edition, Academic Press Inc., Orlando, FL (1982)

13. Park, J. H., "The Effects of Airline Alliances on Markets and Economic Welfare," Transportation Research Part E, Vol. 33, No. 3, pp. 181-195 (1997).

14. Pen, J. T., "A Study on Domestic Airline Competitiveness- The Comparison between Multi-Criteria Decision Making,” Master Thesis, Department of Transportation Management, National Cheng Kung University, Taiwan (1998).

15. Shyr, F. and Chang, L. W., "An Effectiveness Assessment of Code-sharing Practices among Airlines: A Cooperative Game Approach,” Transportation Planning Journal, Vol. 32, No. 4, pp. 601 630 (2003).

16. Suen, W. W., "Alliance Strategy and the Fall of Swissair", Journal of Air Transport Management, Vol. 8, pp. 355-363 (2002).

17. Tseng, C. H., "An Integrated Model for Airline Fleet Routing and Timetable Planning," Master Thesis, Department of Civil Engineering, National Central University, Taiwan (2000).

18. Varian, H., Economic and Financial Modeling with Mathematica, Springer-Verlag Publishers, the Electronic Library of Science, Santa Clara, CA (1993).

19. Youssef, W. and Hansen, M., "Consequences of Strategic Alliances between International Airlines: The Case of Swissair and SAS," Transportation Research Part A, Vol. 28, No. 5, pp. 415-431 (1994). 